\title{
The Saproxylic Activity Index: A New Tool for the Rapid Assessment of Deadwood Species during Forest Restoration
}

\author{
Moya L. Burns ${ }^{1}$, Mike Smith ${ }^{2}$, Eleanor M. Slade ${ }^{1,3}$, Richard A. Ennos ${ }^{4}$ \\ ${ }^{1}$ Department of Zoology, University of Oxford, Oxford, UK \\ ${ }^{2}$ Forest Research, Northern Research Station, Roslin, UK \\ ${ }^{3}$ Department of Agricultural Sciences, University of Helsinki, Helsinki, Finland \\ ${ }^{4}$ School of Biological Sciences, University of Edinburgh, Edinburgh, UK \\ Email: moya.burns@zoo.ox.ac.uk
}

Received December $1^{\text {st }}$, 2013; revised January $7^{\text {th }}$, 2014; accepted January $21^{\text {st }}, 2014$

\begin{abstract}
Copyright (c) 2014 Moya L. Burns et al. This is an open access article distributed under the Creative Commons Attribution License, which permits unrestricted use, distribution, and reproduction in any medium, provided the original work is properly cited. In accordance of the Creative Commons Attribution License all Copyrights (C) 2014 are reserved for SCIRP and the owner of the intellectual property Moya L. Burns et al. All Copyright (C) 2014 are guarded by law and by SCIRP as a guardian.
\end{abstract}

Restoring deadwood habitat is vital in order to recreate fully functioning forest ecosystems. Letting this process occur naturally can take in excess of one hundred years, thus management practises typically try to accelerate this via the artificial addition of deadwood. Since the species which rely on deadwood often have poor dispersal abilities, restoring deadwood habitat rarely results in the full restoration of the saproxylic fauna. Furthermore, standard deadwood monitoring protocol only records the amount and type of substrate available and is not capable of determining whether saproxylic insects have been restored. Full species inventories are time-consuming, costly and require great expertise. We present a rapid biodiversity assessment tool which we believe is the first protocol for measuring saproxylic activity which is accessible to non-specialists. Utilising the exit bore holes which saproxylics create on deadwood can provide an indication of the density, richness and diversity of species present; we call this the Saproxylic Activity Index. We show that this index can detect differences in the activity of insects between substrates. As saproxylic insects provide important ecosystem functions, such as aiding in the decay of deadwood and recycling nutrients, a measure of their activity levels may indicate the rate of restoration of these ecosystem processes. We believe that further exploration of this method provides an exciting opportunity for the functional restoration of saproxylic fauna to become incorporated into mainstream forest management.

Keywords: Citizen Science; Temperate Forest; Beetles; Bioindicators; Volunteers; Coleoptera; Biodiversity; Surveys

\section{Introduction}

Saproxylic insects, those which depend on deadwood or the fungi and microorganisms associated with it (Speight, 1989), are among the most endangered forest species worldwide (Grove \& Stork 1999; Horak et al., 2012). In Europe, natural forest cover has been reduced to a tiny proportion of its original post-glacial area due to the proliferation of agriculture and urbanisation (Peterken, 1996). In addition, the amount of deadwood in remaining forests has been dramatically reduced due to thousands of years of human use of wood for timber and fuel and in more recent times, forest management practises which remove deadwood for safety and aesthetic reasons (Hagan \& Grove 1999). These factors combined mean that the saproxylic fauna of Europe is being lost at an alarming rate (Wallenius et al., 2010). It is assumed that similar processes are occurring to reduce the saproxylic fauna worldwide, though sufficient data and long-term records are lacking (Grove, 2002).

As saproxylic species have been shown to account for anywhere between $20 \%$ to $56 \%$ of all forest-dwelling species (Grove, 2002) the establishment of deadwood habitats during forest restoration is vital in order to restore biodiversity
(Humphrey, 2005). The success of forest restoration treatments often have to be assessed using rapid biodiversity surveys due to limitations on time and funds (Abate, 1992). However, despite their threatened nature, saproxylic insects, along with most other invertebrates, are rarely included in these assessments (Kim, 1993). This is in part due to the difficulty of surveying the saproxylic fauna compared to other insect groups and the continued decline in the number of skilled taxonomists able to identify these species (Hopkins \& Freckleton 2002). Thus, deadwood volume and levels of decay are often surveyed as a surrogate (Rondeux \& Sanchez, 2010), despite the fact that deadwood availability has not been proven to be correlated with diversity or rarity of saproxylic species (Lassauce et al., 2011). Moreover, as many saproxylic species have poor dispersal abilities (Hodge \& Peterken 1998), an increase in deadwood availability during forest restoration will rarely be able to make up for a loss of deadwood habitat in the past. Thus, using current measures of deadwood availability can lead to inaccurate assumptions about the potential restoration of saproxylic fauna to a site.

A more accurate rapid biodiversity assessment tool for sa- 
proxylic beetles is therefore needed; one which can directly measure recent saproxylic activity and not simply habitat available. Monitoring vertebrates through indirect indicators of activity is already commonplace: e.g. dung or faeces counts (Webbon, et al., 2004; Harrington et al., 2008; Cromsigt et al., 2009), tracks (Reynolds et al., 2004) and nests (Laing et al., 2003). In contrast, the potential of signs of invertebrate activity as bioindicators has rarely been investigated, though with a few exceptions (Schlick-Steiner et al., 2006; Gollan et al., 2010).

Many groups of insects are difficult to sample at large spatial and temporal scales, and often require specialist knowledge. Recently, using "citizen scientists" to overcome these problems has gained momentum. While such programmes have existed for many years for the sampling of vertebrates (Silvertown, 2009; Dickinson et al., 2010), only recently has the use of volunteers to collect data on insects been fully utitised (Kuhn et al., 2008; Kaartinen et al., 2013; Slade et al., 2013). Involving citizen scientists allows for large quantities of data to be collected at scales often not possible for a single scientist or habitat manager alone. However, in order for volunteers to make a meaningful contribution, studies and methods need to be carefully designed and accessible to the non-scientist (Lovell et al., 2009).

Many members of the public know very little about the importance of saproxylic invertebrates or even their existence, simply regarding old trees as a hazard (Speight 1989). Thus, finding a tool which could be beneficial to forest managers in assessing saproxylic activity, and which could be extended to members of the public through engagement in citizen science, has the potential to bring this fascinating group to a whole new audience. This in turn could have a long-term impact on the restoration of saproxylic species in general. To quote Daniel Janzen, “If you don't know it, you can't love it, if you don't love it, you won't save it” (Cardoso et al., 2011).

Developing management tools which can assess the activity of saproxylic invertebrates is not only important for the monitoring of biodiversity, but also for the assessment of ecosystem functioning. It has been highlighted recently that the restoration of ecosystem functioning should be a core management goal alongside the more traditional aims of recovering biodiversity and structure (Ruiz-Jaen \& Aide 2005; Benayas et al. 2009; Suding, 2011). Saproxylic insects perform a vital ecosystem service by accelerating the decay process of wood which releases nutrients back into the soil (Swift, 1977; Ulyshen, 2013; Ulyshen \& Wagner, 2013). There is now recognition that a more functional approach to saproxylic insect conservation, one which highlights the role this group of organisms play in nutrient and carbon cycling, could be a fruitful area of future research (Ulyshen, 2013).

Here we present a new tool for rapidly assessing saproxylic functioning by non-specialists, through a direct measure of their activity. Saproxylic invertebrates produce wood bore holes of varying size and shape (Ehnstrohm \& Axelsson, 2002; Speight, 2005), and thus the diversity of bore holes has the potential to be used as an indicator of saproxylic diversity (Angelstam \& Doenz-Breuss, 2004). Bore hole densities have already been successfully used as a measure of bark beetle attack rates (Lozano et al., 1997, Kelsey \& Joseph 2001); the methodology we present expands on this idea of measuring saproxylic activity directly by incorporating a surrogate of community diversity.

We investigated whether factors which are known to affect saproxylic invertebrate diversity also affect bore hole diversity within an oak wood pasture. We hypothesise that some of the factors that affect species diversity of saproxylics will be found to also affect bore hole diversity, indicating the potential for this method as a surrogate to monitor the restoration of saproxylic activity in a site.

\section{Methods}

\section{Study Site}

The study was carried out over 4 weeks in late January to early February 2006 in Dalkeith Old Wood, $11 \mathrm{~km}$ south of Edinburgh, Scotland (5554'17.25"N, $\left.-03^{\circ} 03^{\prime} 52.67 " W\right)$. The site is an ancient oak-wood pasture bordered with semi-natural woodland on the banks of the North and South Esk rivers, covering an area of 26.4 ha within Dalkeith Country Park. The site is an ancient wood pasture, which is defined by the presence of open-grown, old or "veteran" trees in a habitat which is kept open by grazing animals (Hol \& Smith, 2002).

The dominant species in the woodland is oak, a mixture of mature sessile oak (Quercus petraea (Matt.) Liebl.) and pedunculate oak (Quercus robur L.). Ash (Fraxinus excelsior L.), hawthorn (Crataegus monogyna Jacq.) and birch (Betula pendula Roth) are also present in small amounts within the woodland boundary (Johnston, 2002).

\section{Survey Methods}

The sampling area consisted of approximately 1000 oak trees tagged from previous studies. Since trees were tagged linearly, with neighbouring trees bearing similar numbers, stratified random sampling was used to ensure a spread of trees was selected from across the site. Each set of 100 numbered trees was considered a stratum from which 5 trees with rot sites were selected using a random number table, resulting in a total of 45 surveyed trees. At the time of year the study was conducted it was not possible to distinguish between Quercus petraea and Quercus robur and therefore the ratio of each in the survey is not known. In addition, five pieces of fallen deadwood were selected within each stratum using random coordinates.

Substrate characteristics

Three factors known to affect saproxylic invertebrate diversity were surveyed; diameter, rot type and rot site orientation.

Diameter is one of the factors most frequently presumed to affect saproxylic invertebrate diversity on standing or fallen deadwood substrates. There is thought to be greater saproxylic species richness and greater saproxylic abundance on trees and logs with larger diameters (Ranius \& Jansson 2000). The diameter at breast height (dbh, measured at $1.3 \mathrm{~m}$ from the ground) was recorded for all trees surveyed. For fallen deadwood the diameter at the thickest point was measured.

Wood rot is caused by fungal mycelium. There are two main types of wood rot: red/brown rot and white rot. Red/ brown rot fungi decompose wood by primarily using the carbohydrates (cellulose) of the cell walls, where as white rot fungi utilise both the lignin and carbohydrate components (Patton, 1990). These differences are important as they will affect the successsive utilisation of the wood by invertebrates (Speight, 1989). All rot site encountered on fallen logs were surveyed and on trees all rot sites below two metres from the ground were surveyed. The rot type was classified using the English Nature 
Veteran Trees Initiative which defines rot types based on colour and texture and assigns them into categories lettered from A to O (Fay \& De Berker, 1996).

Rot site orientation has been observed to affect the densities of certain saproxylic species (Ranius \& Nilsson 1997), as orientation of rot sites affects sun exposure and microclimate. For this reason direction of rot site (divided into 8 categories NW, N, NE, E, SE, S, SW and W) was recorded.

Saproxylic Activity Index

Bore holes were surveyed using $5 \mathrm{~cm} \times 5 \mathrm{~cm}$ quadrats. For each rot site, five quadrats were surveyed from random points on the rot area. If the rot site was small as many quadrats as could cover the area were surveyed.

Within each quadrat the number of bore holes was counted and recorded according to their diameter and shape. We used three possible shape categories: oval, round and D-shaped, and six size categories: $<1 \mathrm{~mm}, 1 \mathrm{~mm}<2.5 \mathrm{~mm}, 2.5 \mathrm{~mm}<5 \mathrm{~mm}, 5$ $\mathrm{mm}<7.5 \mathrm{~mm}, 7.5 \mathrm{~mm}<10 \mathrm{~mm},>10 \mathrm{~mm}$. This resulted in 18 categories into which bore holes could be classified-referred to as saproxylic activity units (Figure 1). For analysis means were calculated for each rot site, to account for the variation in the number of quadrats among different rot sites, and results scaled to values per $\mathrm{m}^{2}$.

The 18 categories of bore holes, or activity units, were then used to calculate a measure of bore hole density, bore hole richness (overall richness of different types of activity units, analogous to species richness) and a bore hole diversity index using the Shannon-Weiner index. The bore-hole diversity index was calculated using the Shannon-Weiner index as the species accumulation curve demonstrated that all species likely to occur at the site had been sampled (Figure 2) (Magurran, 2004). Together we refer to these measures as the Saproxylic Activity Index.

\section{Statistical Analysis}

Rot sites were treated as independent samples as Ranius and Jansson (2002) argued that each rot site could be viewed as a local population due to the fact that there may be many cycles of generations within one rot site and these populations exist independently of their neighbours. Analyses were carried out using $\mathrm{R}$ version 15 ( $\mathrm{R}$ core team, 2013). Bore hole density, richness and diversity were assessed in relation to substrate diameter using linear regression. Bore hole density, richness and diversity in relation to rot direction and rot type were assessed using one-way ANOVAs. Bore hole density was log-transformed to meet the model requirement of normality.

\section{Results}

\section{Distribution of Insect Bore Holes}

The majority of bore holes were round, accounting for $96 \%$ of bore holes surveyed. Bore holes were far more frequent in the smaller size categories with $81 \%$ of all bore holes having a diameter of less than $1 \mathrm{~mm}$. The most prevalent type of bore hole category in both standing and fallen deadwood was round $<1 \mathrm{~mm}$ diameter, accounting for $80 \%$ of all bore holes surveyed. There were large variations in the density of bore holes between rot sites. The minimum density of bore holes was 320 per $\mathrm{m}^{2}$, the maximum 28,160 per $\mathrm{m}^{2}$ and the average 6495 per $\mathrm{m}^{2}$. Bore hole richness at the study site was 11 out of a possible 18 categories. On fallen deadwood all 11 categories were present; on standing deadwood only nine categories were recorded. Accumulation curves indicated that the sampling effort was sufficient to record all categories likely to be present at the study site (Figure 2).

\section{Factors Affecting the Distribution of Insect Bore Holes}

Bore hole density and diversity showed no relationship with the direction of rot site or the diameter of the substrate (Figure 3(a): $\log$ (bore hole density) diameter: $\mathrm{df}=1, \mathrm{~F}=1.43, p=$ 0.23 ; Figure 3(b): bore hole diversity diameter: $\mathrm{df}=1, \mathrm{~F}=$ 0.003, $p=0.95$; Figure 3(c): $\log$ (bore hole density) rot site direction: $\mathrm{df}=7, \mathrm{~F}=0.38, p=0.91$, Figure $3(\mathrm{~d})$ : bore hole diversity rot site direction $\mathrm{df}=7, \mathrm{~F}=0.365, p=0.92$ ).

\begin{tabular}{|c|c|c|c|}
\hline \multicolumn{4}{|c|}{ Saproxylic Activtity Index Recording Card } \\
\hline \multicolumn{2}{|l|}{$\begin{array}{l}\text { Date: } \\
\text { Location: } \\
\text { Quadrat No.: }\end{array}$} & \multicolumn{2}{|c|}{$\begin{array}{l}\text { Rot Type: } \\
\text { Rot Direction: } \\
\text { Substrate Diameter: }\end{array}$} \\
\hline & Round & Oval & D-Shaped \\
\hline \multicolumn{4}{|l|}{$<1 \mathrm{~mm}$} \\
\hline \multicolumn{4}{|l|}{$1 \mathrm{~mm}<2.5 \mathrm{~mm}$} \\
\hline \multicolumn{4}{|l|}{$2.5 \mathrm{~mm}<5 \mathrm{~mm}$} \\
\hline \multicolumn{4}{|l|}{$5 \mathrm{~mm}<7.5 \mathrm{~mm}$} \\
\hline \multicolumn{4}{|l|}{$7.5 \mathrm{~mm}<10 \mathrm{~mm}$} \\
\hline $10 \mathrm{~mm}$ & & & \\
\hline
\end{tabular}

Figure 1.

Saproxylic activity index recording card and quadrat.

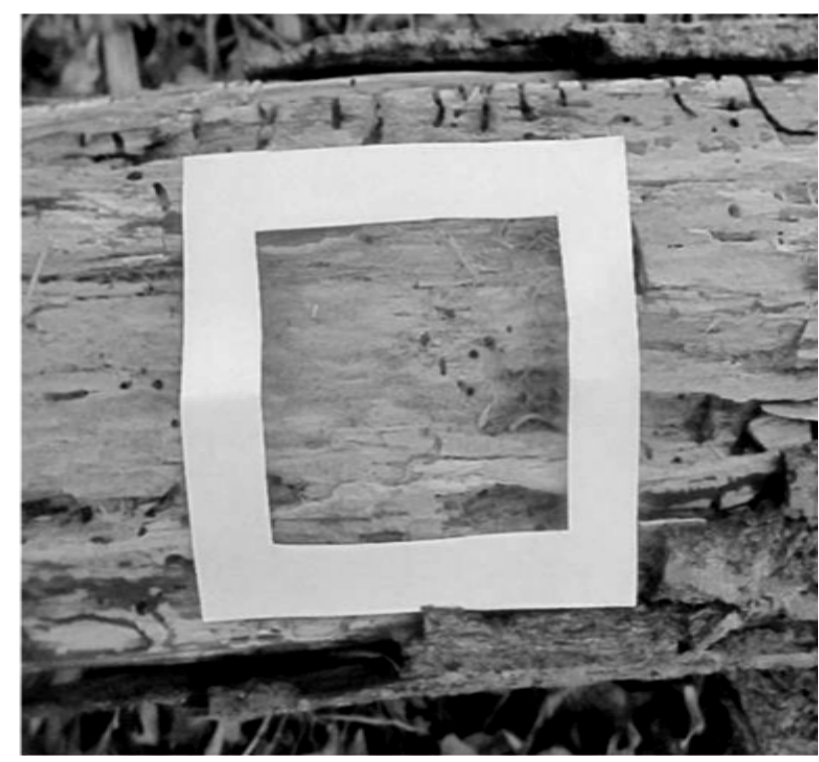



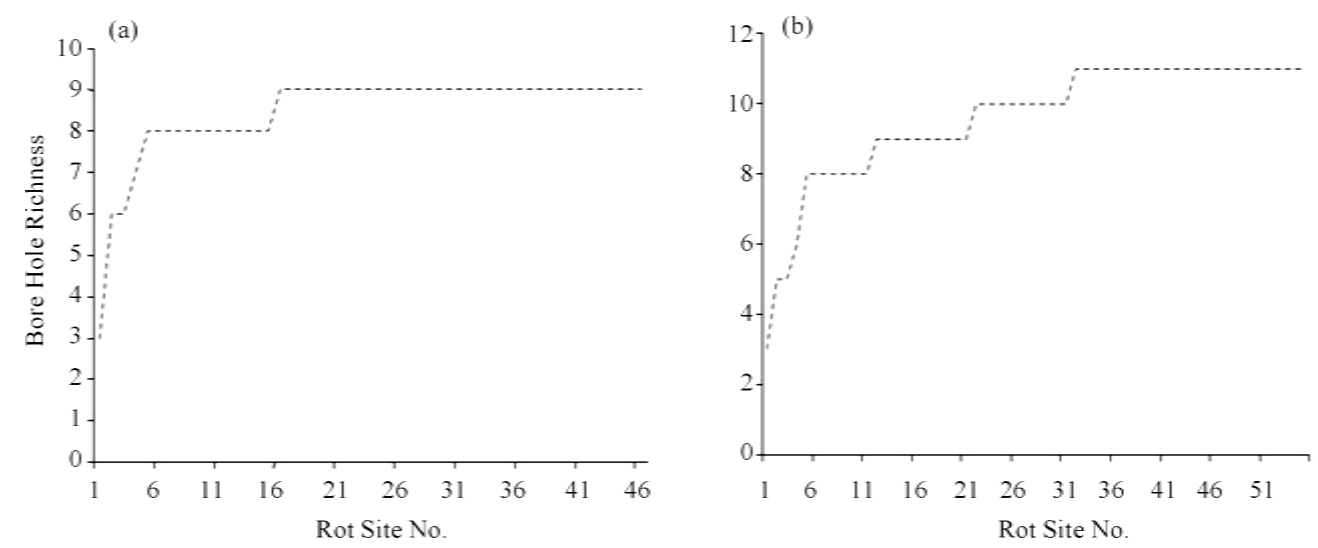

Figure 2.

Bore hole richness accumulation curves for (a) standing deadwood and (b) fallen deadwood.
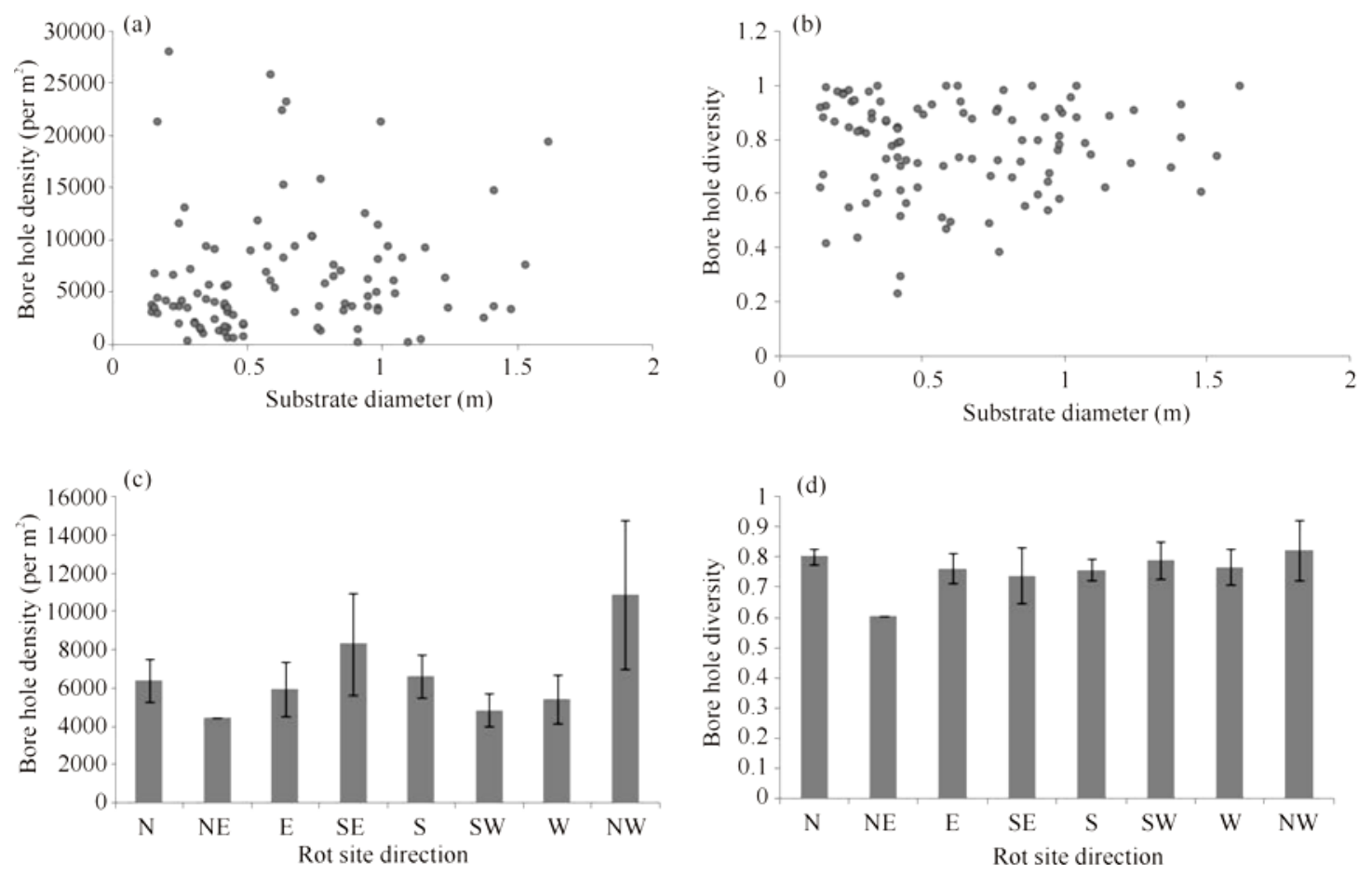

Figure 3.

Bore hole (a) density and (b) diversity in relation to area of substrate (fallen and standing deadwood combined). Bore hole (c) density and (d) diversity in relation to direction of rot-site (fallen and standing deadwood combined). Error bars show standard error of the mean. Only one rot site occurred facing towards the north-east (NE).

Rot type was found to have a significant effect on all measures of the Saproxylic Activity Index. Bore hole density varied significantly between rot types ( $\mathrm{df}=7, \mathrm{~F}=3.27, p=0.004$ ). Rot type G (Red/ Brown Fibrous Moist) was found to have the greatest mean density of insect bore holes and rot type F (Red/ Brown Cubical Dry) the least (Figure 4(a)). Bore hole richness ( $\mathrm{df}=7, \mathrm{~F}=3.11, p=0.009)$ and diversity $(\mathrm{df}=7, \mathrm{~F}=2.30, p=$ 0.042) also differed significantly among rot types. Bore hole richness was greatest on rot type B (White Fibrous Dry) and lowest on rot type P (Black Fibrous Dry) (Figure 4(b)). Rot type A (White Cubical Dry) supported the greatest diversity of bore holes (Figure 4(c)). Since rot type A was observed only once in the field, this data point was removed from the analysis and an a-posteriori ANOVA confirmed that even excluding this there was a significant difference in bore hole diversity between rot types $(\mathrm{df}=6, \mathrm{~F}=2.80, p=0.027)$.

\section{Discussion}

These results open an exciting new avenue of research for the future rapid assessment of saproxylic activity during forest restoration. Rot type was found to affect the density, richness and diversity of insect bore holes, indicating that this method of rapid biodiversity assessment can reflect real differences in the activity of saproxylic insects. Deadwood is already used as an indicator of "old growth" conditions being reached during forest restoration. We argue that direct evidence of the activity of saproxylic invertebrates, such as that demonstrated 

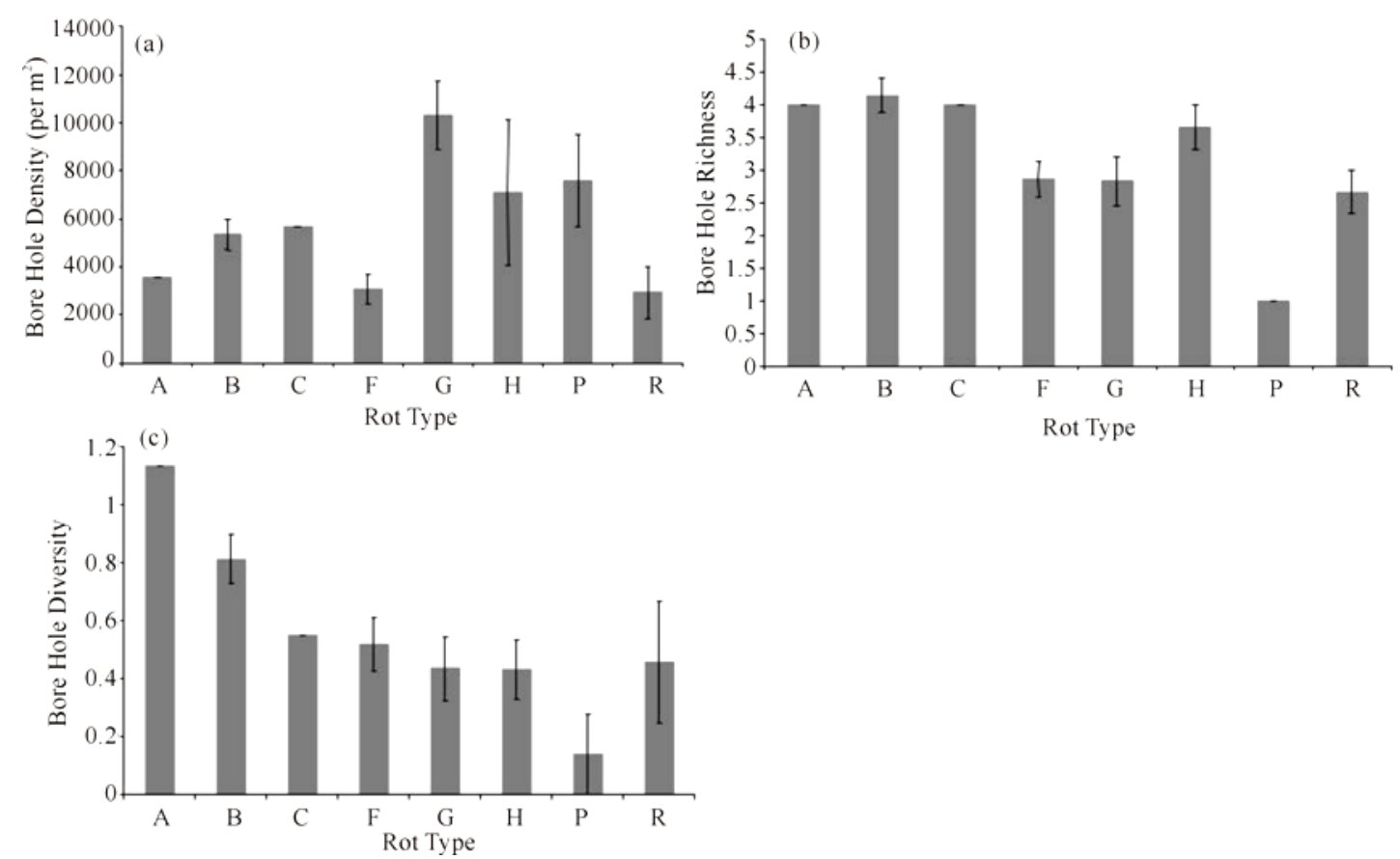

Rot types are classified using the English Nature Veteran Trees Initiative. A = White Cubical Dry, B = White Fibrous Dry, C = White Fibrous Moist, $F=$ Red/Brown Cubical Dry, G = Red/Brown Fibrous Dry, H = Red/Brown Fibrous Moist, $\mathrm{P}=$ Black Fibrous Dry, R = Black Fibrous Moist.

Figure 4.

Bore hole (a) density (b) richness and (c) diversity in relation to rot type (fallen and standing deadwood combined). Error bars show standard error of the mean. Rot type A only occurred once in the survey area.

in this paper, is needed in order to truly establish the success of restoration of deadwood species to a site; the Saproxylic Activity Index offers a viable method by which this can be achieved.

Indicators need to be simple to use and effective in order to show whether management targets are being met (Ferris \& Humphrey, 1999). The Saproxylic Activity Index has the potential to meet these requirements. It is quick, easy to use, and readily accessible to non-specialists, such as habitat managers and citizen scientists. Moreover, it is a non-destructive method of sampling saproxylic invertebrate presence. This is of particular importance due to the already threatened nature of this group (Harvey et al., 2011).

We found that rot type influenced bore hole density, richness and diversity. As wood decays, the host range for saproxylic insects broadens and the flora of decay becomes the most important factor determining the saproxylic fauna (Larkin \& Elbourn, 1964; Jonsell et al., 1998), this may explain the relationship found between rot type and the Saproxylic Activity Index. Rot type A, which only occurred in one site had the highest bore-hole diversity, which may indicate that rare rot types provide habitats for rare species.

It has been hypothesised that saproxylic invertebrates may prefer trees with larger diameters because they have a more stable microclimate (Ranius \& Jansson, 2000). Some studies which have surveyed saproxylic insect fauna using capture methods have provided support for this theory, although they point out that this pattern may be species specific (Ranius \& Jansson, 2002). Our study found no relationship at Dalkeith Old Wood between diameter and the Saproxylic Activity Index, and we suggest that this may be because of the homogeneity of the diameter of standing and fallen deadwood at the study site, due to the uniformity of tree age (Johnston, 2002). Alternatively, it may be that if such diameter effects are not apparent across all saproxylic species then a coarse measure of diversity such as the Saproxylic Activity Index will be unable to detect individual species responses.

A wood pasture by its nature has a far more open canopy than a plantation or semi-natural forest (Hol \& Smith 2002). Most published studies looking at saproxylic invertebrate diversity in relationship to exposure have been carried out in closed canopy forests (Ranius \& Nilsson 1997). This may explain why no pattern between rot site direction and the Saproxylic Activity Index was found in Dalkeith Old Wood.

The relationship between invertebrate bore hole diversity and actual saproxylic invertebrate species diversity is not known, and little information exists on which species produce which size and shape of bore holes. Moreover, some beetles are dimorphic in size, with females larger than males (Hespenheide, 1976), adding further complication to the idea that bore holes of a certain type are representative of a certain species. While we do not suggest that this method provides a substitute for full saproxylic surveys, in times of limited resources and expertise, the Saproxylic Activity Index can act as a coarse measure of the overall saproxylic density, richness and diversity of a site. In particular we suggest that if surveys using the Saproxylic Activity Index are conducted yearly during a forest restoration treatment, then changes in levels of saproxylic activity can be tracked over time.

\section{Conclusion}

Extensive studies aimed at developing umbrella groups of 
saproxylics which can be used as indicators have been largely unsuccessful and results have not been transferable between regions (Jansson et al., 2009). In contrast, measuring activity levels of saproxylics as a measure of ecosystem functioning offers an exciting new area of research, especially if consistent values representing old growth forest can be determined against which survey results can be compared. We hope this paper will stimulate further research into the relationship between the Saproxylic Activity Index and measurable saproxylic insect diversity and ecosystem functioning, such as the rate of wood decay. We anticipate that in future direct evidence of saproxylic activity may become commonplace in rapid biodiversity assessments carried out by forest managers and citizen scientists.

\section{Acknowledgements}

Many thanks are owed to Scottish Natural Heritage for allowing this study to be carried out at Dalkeith Old Wood and for providing background information on the site.

\section{REFERENCES}

Abate, T. (1992). Environmental rapid assessment programs have appeals and critics. BioScience, 42, 486-489.

http://dx.doi.org/10.2307/1311877

Angelstam, P., \& Doenz-Breuss, M. (2004). Measuring forest biodiversity at the stand scale-An evaluation of indicators in European forest history gradients. Ecological Bulletins, 51, 305-332.

Benayas, J. M. R., Newton, A. C. et al. (2009). Enhancement of biodiversity and ecosystem services by ecological restoration: A metaanalysis. Science, 325, 1121-1124.

http://dx.doi.org/10.1126/science.1172460

Cardoso, P., Erwin, T. L. et al. (2011). The seven impediments in invertebrate conservation and how to overcome them. Biological Conservation, 144, 2647-2655.

http://dx.doi.org/10.1016/j.biocon.2011.07.024

Cromsigt, J., van Rensburg, S. J. et al. (2009). Monitoring large herbivore diversity at different scales: Comparing direct and indirect methods. Biodiversity and Conservation, 18, 1219-1231. http://dx.doi.org/10.1007/s10531-008-9506-1

Dickinson, J. L., Zuckerberg, B. et al. (2010). Citizen science as an ecological research tool: Challenges and benefits. Annual Review of Ecology, Evolution, and Systematics, 41, 149-172. http://dx.doi.org/10.1146/annurev-ecolsys-102209-144636

Ehnstrohm, B., \&Axelsson, R. (2002). Insect marks in bark and wood. Uppsala: Art Databanken.

Fay, N., \& De Berker, N. (1996). Veteran trees inititiative, specialist survey method. Peterborough: English Nature.

Ferris, R., \& Humphrey, J. (1999). A review of potential biodiversity indicators for application in British forests. Forestry, 72, 313-328. http://dx.doi.org/10.1093/forestry/72.4.313

Gollan, J. R., Smith, H. M. et al. (2010). Using spider web types as a substitute for assessing web-building spider biodiversity and the success of habitat restoration. Biodiversity and Conservation, 19, 31413155. http://dx.doi.org/10.1007/s10531-010-9882-1

Grove, S., \& Stork N. (1999). The conservation of saproxylic insects in tropical forests: A research agenda. Journal of Insect Conservation, 3, 67-74. http://dx.doi.org/10.1023/A:1009616112275

Grove, S. J. (2002). Saproxylic insect ecology and the sustainable management of forests. Annual Review of Ecology and Systematics, 33, 1-23.

http://dx.doi.org/10.1146/annurev.ecolsys.33.010802.150507

Hagan, J. M., \& Grove, S. L. (1999). Coarse woody debris. Journal of Forestry, 97, 6-11.

Harrington, L. A., Harrington, A. L. et al. (2008). Estimating the relative abundance of American mink Mustela vison on lowland rivers: Evaluation and comparison of two techniques. European Journal of Wildlife Research, 54, 79-87. http://dx.doi.org/10.1007/s10344-007-0114-2

Harvey, D. J., Hawes, C. J. et al. (2011). Development of non-invasive monitoring methods for larvae and adults of the stag beetle, Lucanus cervus. Insect Conservation and Diversity, 4, 4-14. http://dx.doi.org/10.1111/j.1752-4598.2009.00072.x

Hespenheide, H. A. (1976). Patterns in use of single plant hosts by wood-boring beetles. Oikos, 27, 161-164. http://dx.doi.org/10.2307/3543446

Hodge, S. J., \& Peterken, G. F. (1998). Deadwood in British forests: Priorities and a strategy. Forestry, 71, 99-112.

http://dx.doi.org/10.1093/forestry/71.2.99

Hol, K., \& Smith, M. (2002). Ancient wood pasture in Scotland: Classification and management principles. Edinburgh, MB: Scottish Natural Heritage.

Hopkins, G. W., \& Freckleton, R. P. (2002). Declines in the numbers of amateur and professional taxonomists: implications for conservation. Animal Conservation, 5, 245-249. http://dx.doi.org/10.1017/S1367943002002299

Horak, J., Chobot, K. et al. (2012). Hanging on by the tips of the tarsi: A review of the plight of the critically endangered saproxylic beetle in European forests. Journal for Nature Conservation, 20, 101-108. http://dx.doi.org/10.1016/j.jnc.2011.09.002

Humphrey, J. W. (2005). Benefits to biodiversity from developing oldgrowth conditions in British upland spruce plantations: A review and recommendations. Forestry, 78, 33-53.

http://dx.doi.org/10.1093/forestry/cpi004

Jansson, N., Bergman, K. O. et al. (2009). An indicator system for identification of sites of high conservation value for saproxylic oak (Quercus spp.) beetles in southern Sweden. Journal of Insect Conservation, 13, 399-412. http://dx.doi.org/10.1007/s10841-008-9187-9

Johnston, T. G. (2002). Dalkeith old wood. Scottish Forestry, 56, 105111.

Jonsell, M., Weslien, J. et al. (1998). Substrate requirements of redlisted saproxylic invertebrates in Sweden. Biodiversity and Conservation, 7, 749-764. http://dx.doi.org/10.1023/A:1008888319031

Kaartinen, R., Hardwick, B. et al. (2013). Using citizen scientists to measure an ecosystem service nationwide. Ecology, 94, 2645-2652. http://dx.doi.org/10.1890/12-1165.1

Kelsey, R. G., \& Joseph, G. (2001). Attraction of Scolytus unispinosus bark beetles to ethanol in water-stressed Douglas-fir branches. Forest Ecology and Management, 144, 229-238.

Kim, K. C. (1993). Biodiversity, conservation and inventory-Why insects matter. Biodiversity and Conservation, 2, 191-214. http://dx.doi.org/10.1007/BF00056668

Kuhn, E., Feldmann, R. et al. (2008). Getting the public involved in butterfly conservation: Lessons learned from a new monitoring scheme in Germany. Israel Journal of Ecology \& Evolution, 54, 89103. http://dx.doi.org/10.1560/IJEE.54.1.89

Laing, S. E., Buckland, S. T. et al. (2003). Dung and nest surveys: Estimating decay rates. Journal of Applied Ecology, 40, 1102-1111. http://dx.doi.org/10.1111/j.1365-2664.2003.00861.x

Larkin, P. A., \& Elbourn C. A. (1964). Some observation on fauna of dead wood in live oak trees. Oikos, 15, 79-92. http://dx.doi.org/10.2307/3564749

Lassauce, A., Paillet, Y. et al. (2011). Deadwood as a surrogate for forest biodiversity: Meta-analysis of correlations between deadwood volume and species richness of saproxylic organisms. Ecological Indicators, 11, 1027-1039.

http://dx.doi.org/10.1016/j.ecolind.2011.02.004

Lovell, S., Hamer, M. et al. (2009). An assessment of the use of volunteers for terrestrial invertebrate biodiversity surveys. Biodiversity and Conservation, 18, 3295-3307. http://dx.doi.org/10.1007/s10531-009-9642-2

Lozano, C., Kidd, N. A. C. et al. (1997). Effects of parasitoid spatial heterogeneity, sex ratio and mutual interference on the interaction between the olive bark beetle Phloeotribus scarabaeoides (Col., Scolytidae) and the pteromalid parasitoid Cheiropachus quadrum (Hym., Pteromalidae). Journal of Applied Entomology, 121, 521-528. Magurran, A. E. (2004). Measuring biological diversity. Oxford: Blackwell Publishing.

Patton, R. F. (1990). Diseases of forest trees. In R. A. Young, \& R. L. 
Giese (Eds.), Introduction to forest science (pp. 169-194). New York: John Wiley \& Sons.

Peterken, G. F. (1996). Natural woodland. Ecology and conservation in northern temperate regions. Cambridge: Cambridge University Press.

$\mathrm{R}$ Core Team (2013). R: A language and environment for statistical computing. R Foundation for Statistical Computing. http://www.R-project.org

Ranius, T., \& Jansson, N. (2000). The influence of forest regrowth, original canopy cover and tree size on saproxylic beetles associated with old oaks. Biological Conservation, 95, 85-94. http://dx.doi.org/10.1016/S0006-3207(00)00007-0

Ranius, T., \& Jansson, N. (2002). A comparison of three methods to survey saproxylic beetles in hollow oaks. Biodiversity and Conservation, 11, 1759-1771. http://dx.doi.org/10.1023/A:1020343030085

Ranius, T., \& Nilsson, S. G. (1997). Habitat of Osmoderma eremita Scop. (Coleoptera: Scarabaeidae), a beetle living in hollow trees. Journal of Insect Conservation, 1, 193-204. http://dx.doi.org/10.1023/A:1018416000766

Reynolds, J. C., Short, M. J. et al. (2004). Development of population control strategies for mink Mustela vison, using floating rafts as monitors and trap sites. Biological Conservation, 120, 533-543. http://dx.doi.org/10.1016/j.biocon.2004.03.026

Rondeux, J., \& Sanchez, C. (2010). Review of indicators and field methods for monitoring biodiversity within national forest inventories. Core variable: Deadwood. Environmental Monitoring and Assessment, 164, 617-630.

http://dx.doi.org/10.1007/s10661-009-0917-6

Ruiz-Jaen, M. C., \& Aide, T. M. (2005). Restoration success: How is it being measured? Restoration Ecology, 13, 569-577. http://dx.doi.org/10.1111/j.1526-100X.2005.00072.x

Schlick-Steiner, B. C., Steiner, F. M. et al. (2006). Assessing ant assemblages: Pitfall trapping versus nest counting (Hymenoptera, Formicidae). Insectes Sociaux, 53, 274-281.

http://dx.doi.org/10.1007/s00040-006-0869-6

Silvertown, J. (2009). A new dawn for citizen science. Trends in Ecology \& Evolution, 24, 467-471. http://dx.doi.org/10.1016/j.tree.2009.03.017

Slade, E. M., Merckx, T. et al. (2013). Life-history traits and landscape characteristics predict macro-moth responses to forest fragmentation. Ecology, 94, 1519-1530. http://dx.doi.org/10.1890/12-1366.1

Speight, M. C. D. (1989). Life in dead trees-A neglected part of Europe wildlife heritage. Environmental Conservation, 16, 354-356. http://dx.doi.org/10.1017/S0376892900009796

Speight, M. C. D. (1989). Saproxylic invertebrates and their conservation. Nature and environment. Strasbourg: Council of Europe.

Speight, M. R. (2005). Sampling insects from trees: Shoots, stems, and trunks. In Leather, S. R. (Ed.), Insect sampling in forest ecosystems (pp. 77-115). Oxford: Blackwell.

Suding, K. N. (2011). Toward an era of restoration in ecology: Successes, failures, and opportunities ahead. Annual Review of Ecology, Evolution, and Systematics, 42, 465-487.

http://dx.doi.org/10.1146/annurev-ecolsys-102710-145115

Swift, M. J. (1977). The roles of fungi and animals in the immobilization and release of nutrient elements from decomposing branch wood. Ecological Bulletins, 25, 193-202.

Ulyshen, M. D. (2013). Strengthening the case for saproxylic arthropod conservation: A call for ecosystem services research. Insect Conservation and Diversity, 6, 393-395. http://dx.doi.org/10.1111/j.1752-4598.2012.00220.x

Ulyshen, M. D., \& Wagner, T. L. (2013). Quantifying arthropod contributions to wood decay. Methods in Ecology and Evolution, 4, 345-352. http://dx.doi.org/10.1111/2041-210x.12012

Wallenius, T., Niskanen, L. et al. (2010). Loss of habitats, naturalness and species diversity in Eurasian forest landscapes. Ecological Indicators, 10, 1093-1101.

http://dx.doi.org/10.1016/j.ecolind.2010.03.006

Webbon, C. C., Baker, P. J. et al. (2004). Faecal density counts for monitoring changes in red fox numbers in rural Britain. Journal of Applied Ecology, 41, 768-779.

http://dx.doi.org/10.1111/j.0021-8901.2004.00930.x 